coveted posts are divided between the Supreme Government and nine great provinces, each larger than most European States. This would give an average of 1000 posts to each, and an allowance of 500 or 600 Europeans to Delhi and each of the nine subordinate Governments does not seem excessive, especially. when we recall the fact that there is a large European population in the great cities and in the planting and mining districts. It is well to give every scope, in reason, to the ambitions of the $\mathrm{I} \frac{3}{4}$ millions. But the security and tranquillity of the country at large have to be considered.

The figures given by the Commissioners as to the rapidly extending amenities of life in India, of prosperity and education, are very striking. In twenty-four years the railway mileage had increased from 15,245 to 33,599 miles; the passengers carried from $x \times x$ to 437 millions; the freight tonnage from $22 \frac{1}{4}$ millions to 87 millions. A deficit in earnings had been converted into a comfortable net profit of 4,750 ,oool. In twenty years the number of post offices had grown from 8349 to 18,789 . In twenty-six years Indian exports jumped from $60,000,000 l$. to $166,000,000 l$, and imports (a better guide to the spending powers of the people) from 43,500 , oool. to 127,000 , oool. So, in twenty-five years, the pupils in schools rose from $3 \frac{1}{2}$ millions to 7 millions, and girl students from 278,000 to $\mathrm{I}, 000,000$. Other branches of national life show the same marked and sustained progress.

The point for consideration is simply that the spread of prosperity and education tends to multiply the candidates for Government employment so enormously that the resulting feeling of grievance would not be wholly removed even if no imported agency were employed. The Commissioners have, however, suggested the recruiting of 25 per cent. of the Civil Service in India itself. With regard to the many services (smaller, of course, in their numbers) in which there is no question of maintaining British authority, and from which Indians are at present excluded only by want of scientific or technical training, the Commissioners have rightly said that the training should be supplied in India. But the means thereto, now that India is fairly prosperous and on the way to be more so, is to import well-paid European teachers under satisfactory conditions of service and pension. Men of the best type will be needed at home, and if they are to give their services to India, they should receive a sufficient wage. It will be money well spent in the long run, and, in fact, is the only feasible means of creating a large body of scientific technicians and experts in India.

\section{THE NATIONAL IMPORTANCE OF FARM VERMIN.}

SLOWLY but surely the public mind is awakening to the fact that the knowledge that has been obtained through long years of study and observation upon the life-history and habits of animals of all kinds that are injurious to crops is of real importance, and is likely during the next few months to be brought home very vividly even to the most casual. Scientific workers have for long pointed out that all facts hitherto unknown elicited from Nature were of value. Prof. Tyndall nearly fifty years ago told us to keep our sympathetic eye upon the originator of knowledge, but until quite recently such advice has been ignored, if not openly flouted.

For many years past it has been pointed out that the so-called balance of Nature was being disturbed by the thoughtless and ignorant action of certain individuals who openly destroyed owls and kestrels, sparrow-hawks, and other raptorial birds; in like manner the unrestricted increase of such birds as the wood-pigeon, house-sparrow, rook, starling, and blackbird was not only entailing a cruel hardship upon the farmer and fruitgrower, but these very same depredators were reducing the number of our beneficial or insecteating birds to an alarming extent.

At last we have begun to realise that a laissez-faire policy is a mistake, and although somewhat late in the day, the different county, rural, and urban councils are endeavouring to take concerted action to destroy injurious birds and mammals. Excellent as such a movement is, if it has to have a permanent and beneficial effect a mandate from the Board of Agriculture or some other Government Department is needed that will not only permit of the destruction, but, what is equally important, compel the preservation, and to this end much more severe penalties are desirable for those destroying owls, kestrels, lapwings, and the truly insectivorous species of wild birds.

In view of the present shortage of food, which is likely to continue, in probably a lesser degree, for at least a year or two, it is highly important that we should realise the financial loss occasioned by the different species of wild birds and mammals. A recent writer estimates that the loss due to the house-sparrow reaches the incredible figure of $8,000,000 l$. per annum. We shall be well within the mark if we allow double that sum for the depredations of wood-pigeons, rooks, starlings, blackbirds, and other injurious species. It has been computed that the brown rat entails an annual loss to the United Kingdom of upwards of $\mathrm{r} 5,000,000 \mathrm{l}$. The losses due to voles and mice are difficult to arrive at, except in particular years, but it must be considerable. Indeed, it cannot be regarded as an outside estimate if we place the total losses due to the above pests at something like 40,000,00ol. annually.

Now it is patent to any thinking man or woman that we are not doing all that we might, or even anywhere near what we might do, to lessen the enormous national loss. So long as wanton destruction of known beneficial animals is permitted, the unrestricted increase of known and proved injurious species ignored, and an apathy and indifference accorded by the powers that be to those who are endeavouring to awaken the 
public mind on such matters, this enormous waste will continue, and in all probability increase.

It cannot escape observation that for many years past farmers, fruit-growers, and others have annually implored action, but it would seem that the very people who should have been primed with accurate information, and able quickly and decisively to have remedied the situation, are rather disabled than qualified for work of this character, which is of vital importance to the nation, and calls for immediate action.

Walter E. Collinge.

\section{NOTES.}

We learn from the "Political Notes" in the Times that Lord Balfour's Committee on After-War 'Trade has been strengthened by the addition of Sir William Pearce, Sir Charles Henry, Sir Archibald Williamson, and Sir William Priestley. The committee is now in vestigating the question of the possible introduction of the metric and decimal systems for our coinage, weights, and measures.

While the wastage of the Yorkshire cliffs is to be deplored, the result is sometimes of advantage to the geologist and antiquary. Recently, in the vicinity of Scarborough, a fall of the cliff has revealed a hoard of twenty bronze weapons, which consisted of battleaxes, spears, chisels, gouges, portions of a sword, etc. Twelve of the axes, of the socketed type, 'are perfect. One shows the unusual feature of a rivethole in place of a loop for secure hafting; another contained a portion of the original wood shaft. Some of the axes are in the rough state, as if just turned out of the mould; others have obviously been in use. The collection evidently formed the stock-in-trade of a metal-worker of the Bronze Age, at least a thousand years before the Christian era. Mr. T. Sheppard, who has made a special study of the relics of this period, is figuring and describing the specimens, which have found a permanent home in the museum at Hull.

UNTIL recently our supplies of acetone, of which enormous quantities are now required in the manufacture of propellent explosives, have been largely obtained from foreign countries, where cheap supplies of waste wood were available for destructive distillation for acetone production. Since the outbreak of war, however, this position has been radically altered, and acetone is now produced in this country on a large scale by the distillation of wood and in other ways. The question is also being taken up in other countries of the Empire; it is proposed, for instance, to erect a factory for this purpose in Natal, where wattle wood will be used as a raw material. The possibility of similarly utilising the wattle wood accumulated in connection with the wattle bark industry of the East Africa Protectorate is also under consideration, and at the Imperial Institute an exhaustive series of trial distillations with this wood, and also with olive wood from the same protectorate, used locally as fuel, has just been concluded. The results show that the yield of acetone and acetic acid from both woods is satisfactory. A good yield of acetic acid is also being obtained in Ceylon from the distilla. tion of coconut shells and various local woods. Attention is also being given to the subject in the Indian State of Mysore, and it seems likely that in a short time the Empire will be able to produce all the acetone and acetic acid it requires.

No. 2479, VOL. 99]
THE death is announced, in his seventy-ninth year, of Dr. H. B. Wheatley, who was clerk to the Royal Society from 1861 to 1879 , and assistant secretary to the Royal Society of Arts from 1879 to 1908.

We regret to see in the Morning Post of April 27 the announcement of the death of Sir Marc Ruffer, president of the Sanitary, Maritime, and Quarantine Council of Egypt, and formerly director of the British Institute of Preventive Medicine-now the Lister Institute.

THE Nieure Courant announces the death of Prof. Morjan Raciborski, professor of botany in the University of Cracow, and formerly for many years engaged in work on sugar-cane and tobacco in the Buitenzorg Botanic Gardens, Java.

THE valuable material collected by the special commission appointed to investigate the flora, fauna, and hydrology of Lake Baikal is to be published by the Imperial Academy of Sciences, Petrograd, in one volume, of which an edition of five hundred copies will be issued.

We regret to note that Engineering for April 27 records the death of $\mathrm{Mr}$. Andrew S. Biggart, in Glasgow, on April 26. Mr. Biggart was associated with the late Mr. William Arrol for thirty-four years, and took a prominent part in the construction of the plant used in connection with the Forth Bridge. He was a member of the Institution of Civil Engineers, and was noted for his interest in his workers. His death will be regretted by many who have benefited by his philanthropic schemes.

Ar a meeting held at the Institute of Chemistry on April 27, the president and council presented a silver rose bowl to Mr. R. B. Pilcher, registrar and secretary, in appreciation of twenty-five years' faithful service. The meeting was well attended, and the presentation was made by the president, Sir James Dobbie, principal of the Government laboratories. Mr. Pilcher, who joined the staff of the Institute as clerk in 1892 , was appointed assistant secretary in I894, secretary in 1895 , and has held the joint offices of registrar and secretary since 1900 .

IT is announced that the next triennial prize of $300 l$. under the will of the late Sir Astley Cooper will be awarded for an essay or treatise on the subject of "Gunshot Wounds of the Lungs and Pleura." Candidates (who must not be members of the staffs of Guy's or St. Thomas's Hospitals, or their relatives) must send their essays, written in English, addressed to the physicians and surgeons, Guy's Hospital, London, S.E., on or before January I, rgig. Full particulars concerning the conditions of the competition are obtainable from Mr. C. H. Fagge, Guy's Hospital.

THE sixteenth biennial Dutch Congress of Natural and Medical Sciences was held at The Hague on April I 2 and following days. In connection with this, the geography section had organised an interesting his. torical exhibition, mainly of the work of Mercator and the Dutch cartographers of the seventeenth century. The chief general lecture was delivered by Prof. H. A. Lorentz, of Leydin, on "Einstein's Gravitational Theory and Fundamental Ideas in Physics." From a discussion, in one of the sections, on chemical industry in Holland, it appears that the manufacture of aniline and other intermediate materials for the dye industry was started in 1916 .

THE annual meeting of the members of the Royal Institution was held on May I, the Duke of North- 